\title{
Ecotoxicological and biochemical effects of environmental concentrations of the plastic-bond pollutant dibutyl phthalate on Scenedesmus sp.
}

\author{
César Cunha $^{\mathrm{a}}$, Jorge Paulo ${ }^{\mathrm{a}}$, Marisa Faria ${ }^{\mathrm{a}, \mathrm{b}}$, Manfred Kaufmann ${ }^{\mathrm{c}, \mathrm{d}}$, Nereida Cordeiro ${ }^{\mathrm{a}, \mathrm{d}, *}$ \\ ${ }^{a}$ LB3 - Faculty of Science and Engineering, University of Madeira, 9000-390 Funchal, Portugal \\ ${ }^{\mathrm{b}}$ Oceanic Observatory of Madeira (OOM), ARDITI, Madeira Tecnopolo, 9020-105 Funchal, Portugal \\ ${ }^{c}$ Marine Biology Station of Funchal, Faculty of Life Sciences, University of Madeira, 9000-107 Funchal, Portugal \\ ${ }^{\mathrm{d}}$ CIIMAR - Interdisciplinary Centre of Marine and Environmental Research, University of Porto, 4450- 208 Matosinhos, Portugal
}

\section{A R T I C L E I N F O}

\section{Keywords:}

Scenedesmus sp.

Dibutyl phthalate

Ecotoxicity

Environmental endocrine disruptor

Plastic-bond pollutant

\begin{abstract}
A B S T R A C T
Phthalate esters are highly present in aquatic plastic litter, which can interfere with the biological processes in the wildlife. In this work, the commonly found freshwater microalga Scenedesmus sp. was exposed to environmental concentrations $\left(0.02,1\right.$ and $\left.100 \mu \mathrm{g} \mathrm{L}^{-1}\right)$ and to a higher concentration $\left(500 \mu \mathrm{g} \mathrm{L}^{-1}\right)$ of dibutyl phthalate (DBP), which is an environmental pollutant. The growth, $\mathrm{pH}$ variation, production of photosynthetic pigments, proteins and carbohydrates were evaluated. The main inhibition effect of DBP on the microalgal growth was observed in the first $48 \mathrm{~h}$ of the exposure $\left(\mathrm{EC}_{50}: 41.88 \mu \mathrm{g} \mathrm{L}^{-1}\right)$. A reduction in the photosynthetic pigment concentration was observed for the $0.02,1$ and $100 \mu \mathrm{g} \mathrm{L}^{-1}$ conditions indicating that the DBP downregulated the growth rate and affected the photosynthetic process. A significant increase in protein production was only observed under $500 \mu \mathrm{g} \mathrm{L}^{-1}$ DBP exposure. The extracellular carbohydrates production slightly decreased with the presence of DBP, with a stronger decrease occurring in the $500 \mu \mathrm{g} \mathrm{L}^{-1}$ condition. These results highlight the environmental risk evaluation and ecotoxicological effects of DBP on the production of biovaluable compounds by microalgae. The results also emphasize the importance of assessing the consequences of the environmental concentrations exposure as a result of the DBP dose-dependent correlation effects.
\end{abstract}

\section{Introduction}

The global exponential plastic production and consumption is becoming an increasingly relevant issue. In 2018, the annual plastic production was 400 million tons of which about 13 million leaks into open waters each year (UN environment, 2018). Moreover, future trends predict that plastic production may ascend up to 1800 million each year (Ryan, 2015). Furthermore, the plastic aquatic debris that floats in the water suffers from mechanical action and UV-radiationinduced-photooxidation, leading to a loss of mechanical integrity (GESAMP, 2015). This causes the release of even smaller sized polymer fragments known as microplastics (plastic particles smaller than $5 \mathrm{~mm}$ ). Microplastics are found all over the globe in different water sources including our oceans (Waller et al., 2017; Peeken et al., 2018; Desforges et al., 2014), rivers (Hurley et al., 2018) and have been shockingly found in up to $90 \%$ of bottled drinking water (Mason et al., 2018). Additionally, microplastics have been reported to adsorb different types of persistent organic pollutants (POPs), which include, among others, polycyclic aromatic hydrocarbons (PAHs) and polychlorinated biphenyls (PCBs) (Besseling et al., 2013; Endo et al., 2015; Frias et al., 2010; Hirai et al., 2011; Mato et al., 2001; Teuten et al., 2007). Furthermore, microplastics contain in their composition phthalate esters (PAEs), which include dibutyl phthalate (DBP) (Fries et al., 2013), an environmental contaminant that has become one of the primary PAEs present in the aquatic environment ( $\mathrm{Gu}$ et al., 2017). They, or their degradation products (Jonsson and Baun, 2003), are transported through the aquatic environments (Bakir et al., 2014), affecting wildlife (Huang et al., 1999; Ohtani et al., 2000), more specifically phytoplankton. DBP is an aliphatic ester additive that is used as a plasticizer to improve its flexibility and durability, with PAE's accounting for $10-70 \%(\mathrm{w} / \mathrm{w})$ of all plastics (Nerland et al., 2014). Therefore, PAEs are easily diffused into the surroundings due to their weak Van der Waals bonds to plastic, which facilitates their perturbation and consequent release from their substrate ( $\mathrm{Gu}$ et al., 2017). Moreover, DBP is also classified as a xenoestrogen and has the potential to bind to estrogen receptor sites (Müller et al., 2000). This could likely interfere with various biological processes in wildlife (Ohtani et al., 2000) which even at trace concentrations, could have potentially hazardous effects (Gao

\footnotetext{
* Corresponding author.

E-mail address: ncordeiro@staff.uma.pt (N. Cordeiro).
} 
and Wen, 2015a). DBP is consistently found in freshwaters, with the lowest detected concentration being $0.002 \mu \mathrm{g} \mathrm{L}{ }^{-1}$ (Fatoki et al., 2010) and the highest $122 \mu \mathrm{g} \mathrm{L}^{-1}$ (Gao and Wen, 2015a), depending on the location. As it follows, the studies published about the DBP ecotoxicity use very high concentrations of this pollutant, outside the range or near the maximum concentration found in the environment. This may lead to biased conclusions on the true effect of this pollutant on microalgae and therefore needs to be clarified. Thus, the exposure to DBP has shown inconsistent results in ecotoxicological tests, evidencing growth inhibition in the $50-100 \mathrm{mg} \mathrm{L}^{-1}$ concentration range, while stimulating growth in the $5-20 \mathrm{mg} \mathrm{L}^{-1}$ concentration range in Chlorella vulgaris (Duan et al., 2018). Furthermore, it has also shown growth stimulation before the inhibition in the $1-8 \mathrm{mg} \mathrm{L}^{-1}$ concentration interval in $\mathrm{Mi}$ crocystis aeruginosa (Chunxiao et al., 2015). The studies found involving Scenedesmus species show that DBP displays toxicity towards Scenedesmus obliquus ( $96 \mathrm{~h}-\mathrm{EC}_{50}$ : $0.21 \mu \mathrm{g} \mathrm{L}^{-1}$ ) and a growth inhibition up to $80 \%$ was verified at $20 \mathrm{mg} \mathrm{L}^{-1}$ concentration (Gu et al., 2017). Huang et al. (1999) showed that the DBP was degraded by this microalga. However, Babu and $\mathrm{Wu}, 2010$ report that some freshwater algae and cyanobacteria can synthesize PAEs, including DBP, and release them into the extracellular medium under stress conditions.

Taking into account the known effects on the microalgal growth, it is important to understand how the biochemistry of the microalgae is affected by the presence of DBP, as a result of the industrial and commercial importance of its biovaluable compounds. Every microalga produces different ratios of pigments and valuable molecules, including proteins and carbohydrates, due to different metabolism rates. Scenedesmus sp. is a freshwater chlorophycean alga (Cambiaire et al., 2006) that is widely used in ecotoxicological studies. It possesses the ability to quickly adapt and manipulate its metabolism to adjust to the presence of potentially hazardous substances (Mandal and Mallick, 2009).

This investigation seeks to determine the toxic effects of DBP on a realistic concentration range, found in the environment, assessing the risk that this pollutant has on the microalgae development. Thus, in this study, the influence of natural occurring concentrations of DBP $(0.02,1$ and $\left.100 \mu \mathrm{g} \mathrm{L}^{-1}\right)$ and a higher laboratory concentration $\left(500 \mu \mathrm{L} \mathrm{L}^{-1}\right)$ on Scenedesmus sp. biochemical activity was evaluated. The growth, as well as $\mathrm{pH}$ variation, photosynthetic pigments, extracellular proteins and carbohydrates production were assessed. Simple and reliable analytical tests were applied to screen, in a convenient and reliable way, the more intrinsic changes that exposure to environmental concentrations of hazardous pollutants induce. DBP stability was assessed by ultra-high-performance liquid chromatography (UHPLC).

\section{Materials and methods}

\subsection{Microalgae selection and culture conditions}

In the present study, the freshwater microalga Scenedesmus sp. (Class Chlorophyceae; 5-13 $\mu \mathrm{m}$ ) was selected. Scenedesmus sp. (BEA0579B) was obtained from the Spanish Bank of Algae (BEA) of the University of Las Palmas de Gran Canaria (Spain) (Cunha et al., 2019) and was grown in Waris- $\mathrm{H}$ medium $\left(0.1 \mathrm{gL}^{-1} \mathrm{KNO}_{3} ; 0.02 \mathrm{~g} \mathrm{~L}^{-1}\right.$ $\mathrm{MgSO}_{4} .7 \mathrm{H}_{2} \mathrm{O} ; \quad 0.02 \mathrm{~g} \mathrm{~L}^{-1} \quad\left(\mathrm{NH}_{4}\right)_{2} \mathrm{HPO}_{4} ; 0.1 \mathrm{gL}^{-1} \mathrm{Ca}\left(\mathrm{NO}_{3}\right)_{2} .4 \mathrm{H}_{2} \mathrm{O}$; $0.24 \mathrm{~g} \mathrm{~L}^{-1}$ HEPES; PII Metals $\left(0.003 \mathrm{~g} \mathrm{~L}^{-1}\right.$ Titriplex III; $0.001 \mathrm{~g} \mathrm{~L}^{-1}$ $\mathrm{H}_{3} \mathrm{BO}_{3} ; \quad 0.00014 \mathrm{gL}^{-1} \quad \mathrm{MnCl}_{2} .4 \mathrm{H}_{2} \mathrm{O} ; 0.00021 \mathrm{~g} \mathrm{~L}^{-1} \quad \mathrm{ZnSO}_{4} .7 \mathrm{H}_{2} \mathrm{O}$; $\left.0.000004 \mathrm{~g} \mathrm{~L}^{-1}\right)$; Fe-EDTA $\left(0.0052 \mathrm{~g} \mathrm{~L}^{-1}\right.$ Tritiplex II; $0.0049 \mathrm{~g} \mathrm{~L}^{-1}$ $\mathrm{FeSO}_{4} .7 \mathrm{H}_{2} \mathrm{O} ; 0.054 \mathrm{~mL} \mathrm{~L}^{-1} 1 \mathrm{~N} \mathrm{KOH}$; Vitamins $\left(0.0002 \mathrm{mg} \mathrm{L}^{-1}\right.$ Vitamin B12; $0.001 \mathrm{mg} \mathrm{L}^{-1}$ Biotin; $0.1 \mathrm{mg} \mathrm{L}^{-1}$ Thiamine $-\mathrm{HCl}$; $0.0001 \mathrm{mg} \mathrm{L}^{-1}$ Niacinamide); $10 \mathrm{~mL} \mathrm{~L}^{-1}$ Soil Extract). The initial selected cell abundance was $1.6 \times 10^{5}$ cells $\mathrm{mL}^{-1}$, following the Organization for Economic Cooperation and Development (OECD) guidelines for the testing of chemicals in freshwater microalgae (OECD, 2011). These conditions ensure that the culture can grow exponentially throughout the incubation period. The growth was monitored every $24 \mathrm{~h}$, for $96 \mathrm{~h}$, using a Neubauer improved chamber with an optical microscope $(\times 400)$ (Olympus BX41 Microscope) and the microalgal cell abundance was used to determine the potential effects of exposure to DBP. The experimental cultures were maintained at $25 \pm 1{ }^{\circ} \mathrm{C}$, under the irradiance of $23.5 \mu \mathrm{mol}$ photons $\mathrm{m}^{-2} \mathrm{~s}^{-1}$ (HOBO ${ }^{\circledR}$ Pendant $^{\circledR}$ MX Temp MX2201) provided by a cool white Osram L $18 \mathrm{~W} 840$ Lumilux lamp, with a 14/10h (light/dark) photoperiod (Aralab CP500 growth chamber).

\subsection{Microalgae exposure conditions to DBP and growth inhibition test}

The microalgae were subjected to four different concentrations of DBP (99\%; Riedel-de Haën): 0.02, 1 and $100 \mu \mathrm{g} \mathrm{L}^{-1}$ (named environmental concentrations) and $500 \mu \mathrm{g} \mathrm{L}^{-1}$ (named laboratory concentration). Following the OECD guidelines (OECD, 2011), the DBP was dissolved in methanol (99.8\%; Sigma-Aldrich ${ }^{\circledast}$ ), with the maximum amount of the solvent set to $0.05 \%$ in the test culture, for all conditions and replicates. Control groups with and without methanol were prepared. The control groups were used to evaluate whether they would have an influence on the microalgal growth. The cultures were acclimatized in the experimental conditions for $96 \mathrm{~h}$ before inoculation. For the experiments (made in triplicate), fresh medium was added in order to achieve an initial cell abundance of $1.6 \times 10^{5}$ cells $\mathrm{mL}^{-1}$. All flasks were hand-shaken twice per day during the experimental period.

According to the OECD (OECD, 2011), the $\mathrm{EC}_{50}$ was calculated using a linear regression of the inhibition rate and expressed in terms of the DBP concentration $\left(\mu \mathrm{g} \mathrm{L}^{-1}\right)$. Also, in short and according to the OECD guidelines, the LOEC was determined as "the lowest tested concentration at which the substance is observed to have a statistically significant reducing effect on growth (at $\mathrm{p}<0.05$ ) when compared with the control, within a given exposure time" (OECD, 2011).

\subsection{DBP stability analysis}

The DBP stability in the culture medium, without microalga, was analysed at 0,48 and $96 \mathrm{~h}$ using ultra high-performance liquid chromatography (UHPLC). The analysis was performed in a Shimadzu Nexera X2 system equipped with a LC-30CE pump, a SIL-30AC autosampler, a $D G U-20 A(S R)$ degasser, a CTO-20AC column oven, coupled to a SPD-M2OA photodiode array detector. A Shimadzu Shim-pack GIST C18 column $(2.1 \times 100 \mathrm{~mm}, 2 \mu \mathrm{m})$ was used at a constant oven temperature of $25{ }^{\circ} \mathrm{C}$ with an isocratic flow of methanol/water $(88: 12, \mathrm{v} / \mathrm{v})$ at a flow rate of $0.3 \mathrm{~mL} \mathrm{~min}^{-1}$. The injection volume for each sample was $25 \mu \mathrm{L}$ and the DBP was detected at a wavelength of $230 \mathrm{~nm}$. Due to detection limits, the only concentration of DBP used was $500 \mu \mathrm{g} \mathrm{L}^{-1}$.

\subsection{Photosynthetic pigments determination}

The photosynthetic pigment production was determined based on the Lichtenthaler (1987) method, with some modifications. Briefly, $5 \mathrm{~mL}$ culture was centrifuged at 13,400 rpm for $2 \mathrm{~min}$, the supernatant discarded, and the pellet resuspended in $5 \mathrm{~mL}$ of $90 \%$ methanol. The sample was then sonicated for $5 \mathrm{~min}$ at room temperature, incubated in the dark at $4{ }^{\circ} \mathrm{C}$ for $24 \mathrm{~h}$ and centrifuged (13,400 rpm, $\left.2 \mathrm{~min}\right)$. Chlorophyll $a$ (chl-a), chlorophyll b (chl-b) and total carotenoids (car-t) were determined at $470\left(\mathrm{~A}_{470}\right), 652\left(\mathrm{~A}_{652}\right)$ and $665 \mathrm{~nm}\left(\mathrm{~A}_{665}\right)$, and corrected by subtracting the absorbance at $750 \mathrm{~nm}$ (turbidity), using the following equations:

chl-a $\left(\mu \mathrm{g} \mathrm{mL}{ }^{-1}\right)=16.82 \mathrm{~A}_{665}-9.28 \mathrm{~A}_{652}$

chl-b $\left(\mu \mathrm{g} \mathrm{mL}^{-1}\right)=36.92 \mathrm{~A}_{652}-16.54 \mathrm{~A}_{665}$

car-t $(\mu \mathrm{g} \mathrm{mL}$

\subsection{Extracellular protein determination}

In order to determine the proteins in the supernatant (extracellular proteins) a modified Lowry et al. (1951) method was implemented. 
Cultures were centrifuged at $5000 \mathrm{rpm}$ for $20 \mathrm{~min}$, at $25^{\circ} \mathrm{C}$ to remove microalgae and other debris. The centrifugation time and speed were adjusted to the cell density of the sample to assure a cell-free supernatant. Reagent $\mathrm{A}\left(2 \% \mathrm{Na}_{2} \mathrm{CO}_{3}\right.$ in $\left.0.1 \mathrm{~N} \mathrm{NaOH}\right)$ was mixed with reagent $\mathrm{B}\left(1 \% \mathrm{C}_{6} \mathrm{H}_{5} \mathrm{Na}_{3} \mathrm{O}_{7}\right.$ in $\left.0.5 \% \mathrm{CuSO}_{4}\right)$ in a $50: 1$ ratio (reagent $\left.\mathrm{C}\right)$ and the Folin-Ciocalteu reagent was diluted in a 1:1 ratio. In a test tube, $2.5 \mathrm{~mL}$ of reagent $\mathrm{C}(15 \mathrm{~min})$ and $250 \mu \mathrm{L}$ of Folin-Ciocalteu were added to $500 \mu \mathrm{L}$ of sample, vortexed and left for $35 \mathrm{~min}$ to react. Absorbance was measured at $750 \mathrm{~nm}$ and a standard calibration curve was made using bovine serum albumin (BSA). A stock solution of $5 \mathrm{mg} \mathrm{mL}^{-1}$ was freshly prepared, which was diluted to $10,20,50,100,200,500,1000$ and $2000 \mu \mathrm{g} \mathrm{mL}{ }^{-1}\left(\mathrm{R}^{2}=0.9301\right)$.

\subsection{Extracellular carbohydrates determination}

The extracellular carbohydrates were determined using the phenolsulfuric acid method, according to DuBois, et al. (1956), where $1 \mathrm{~mL}$ of $5 \%$ phenol aqueous solution was added to the supernatant $(2 \mathrm{~mL})$ of the centrifuged culture ( $5000 \mathrm{rpm}, 20 \mathrm{~min}$ ). This was promptly followed by $5 \mathrm{~mL}$ of concentrated sulfuric acid that was left for $10 \mathrm{~min}$ to react and vortex. It was then left for another $20 \mathrm{~min}$ in a room temperature water bath for colour development to take place. The absorbance was measured at $490 \mathrm{~nm}$ in an UV-6300 PC Double Beam Spectrophotometer, in $1.5 \mathrm{~mL}$ semi-micro PS disposable cuvettes (Plastibrand ${ }^{\circledast}$ ). A calibration curve was made with D-(+)-Glucose (99.5\%, Sigma Aldrich $\left.{ }^{\circledast}\right)$, using a freshly prepared stock solution (500 $\mathrm{mg} \mathrm{L}^{-1}$ ) diluted to $5,10,15,20,25$ and $50 \mathrm{mg} \mathrm{L}^{-1}\left(\mathrm{R}^{2}=0.9575\right)$.

\subsection{Statistics analysis}

Statistical analysis of microalgal growth rate, $\mathrm{pH}$ variation, photosynthetic pigments, extracellular proteins and carbohydrates production were performed using IBM SPSS statistics software (V.25). The differences in the growth rates and the biochemical activity between different experimental conditions were assessed by a one-way analyses of variance (ANOVA), with a level of statistical significance of $p$ value $<0.05$

\section{Results}

\subsection{DBP stability and effect on the microalga growth}

In order to study the DBP's stability, its algal-free medium concentration was evaluated using UHPLC (Fig. 1). Measurements were performed at 0,48 and $96 \mathrm{~h}$. The results show a considerable decrease of $32.4 \%$ (to $338 \mu \mathrm{g} \mathrm{L}^{-1}$ ) in DBP concentration in the first $48 \mathrm{~h}$ and a

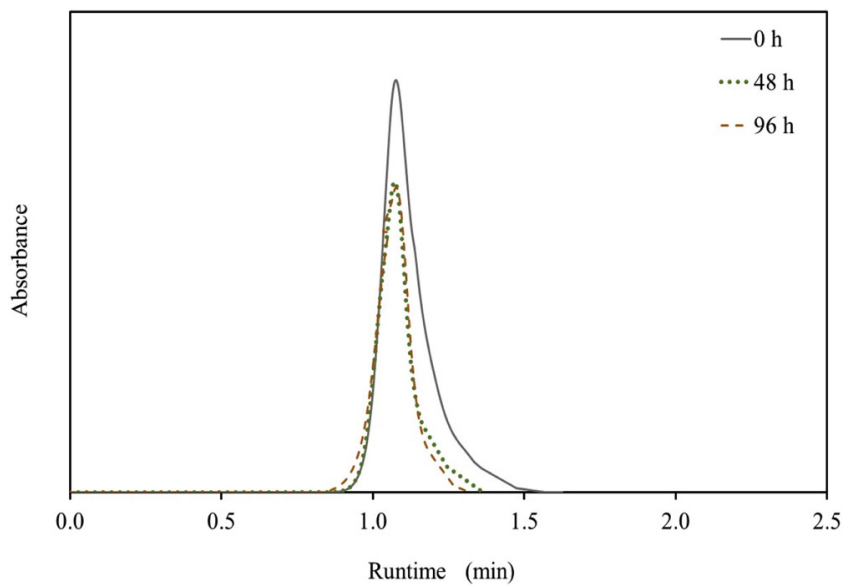

Fig. 1. UHPLC analysis of DBP stability in the culture medium, without microalga, at $500 \mu \mathrm{g} \mathrm{L}^{-1}$.

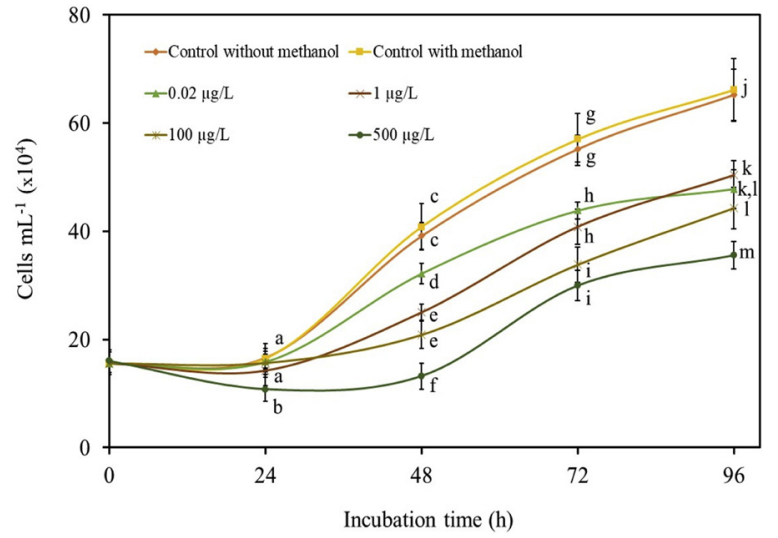

Fig. 2. Growth curves for all the experimental groups. Scenedesmus sp. initial cell abundance was $1.6 \times 10^{5}$ cells $\mathrm{mL}^{-1}$. Distinct letters represent the means significantly different $(p<0.05)$.

further negligible decline of $0.1 \%$ (to $337.5 \mu \mathrm{g} \mathrm{L}^{-1}$ ) in the last $48 \mathrm{~h}$ of the experiment. Therefore, the loss of DBP was only significant in the first $48 \mathrm{~h}$ of the experiment.

Scenedesmus sp. cell abundance was determined in order to assess the DBP ecotoxicity on its growth. To evaluate if methanol would have an impact on the microalgal growth, controls with and without methanol were compared. The results shown in Fig. 2 exhibit that there are no significant differences $(p<0.05)$ in the control conditions, evidencing that the presence of $0.05 \%(\mathrm{v} / \mathrm{v})$ methanol did not influence Scenedesmus sp. growth. Therefore, every test was performed using the control with methanol.

The cell density assessment (Fig. 2) displays the decrease in cell abundance, in every DBP exposed condition, in relation to the control at $24,48,72$ and $96 \mathrm{~h}$ which indicates that DBP displayed a growth inhibition effect.

Unlike the $0.02,1$ and $100 \mu \mathrm{L} \mathrm{L}^{-1}$ conditions, the $500 \mu \mathrm{g} \mathrm{L}^{-1}$ condition exhibited an already significant growth inhibition at $24 \mathrm{~h}$. The inhibition was evident for all concentrations at $48 \mathrm{~h}$ with an $\mathrm{EC}_{50}$ of $41.88 \mu \mathrm{g} \mathrm{L}{ }^{-1}$. Soon after the cell abundance started to steadily increase until the last $48 \mathrm{~h}$ of the experiment. Also, the DBP exposure showed a LOEC (lowest observed effect concentration) of $1 \mu \mathrm{g} \mathrm{L}^{-1}$.

Respecting the $\mathrm{pH}$ variation, Fig. 3 shows that the results follow the OECD guidelines for the experiments of chemicals in freshwater microalgae (OECD, 2011), with the $\mathrm{pH}$ not increasing to more than 1.5 units during the test. The control experiment exhibited the biggest $\mathrm{pH}$ drift, with a decrease of $1.07 \mathrm{pH}$ units at $48 \mathrm{~h}$. In all the DBP exposed conditions, the $\mathrm{pH}$ dropped in the first $24 \mathrm{~h}$, followed by a stable increase in pH after $24 \mathrm{~h}$, until the end of the experiment. The $500 \mu \mathrm{g} \mathrm{L}^{-1}$

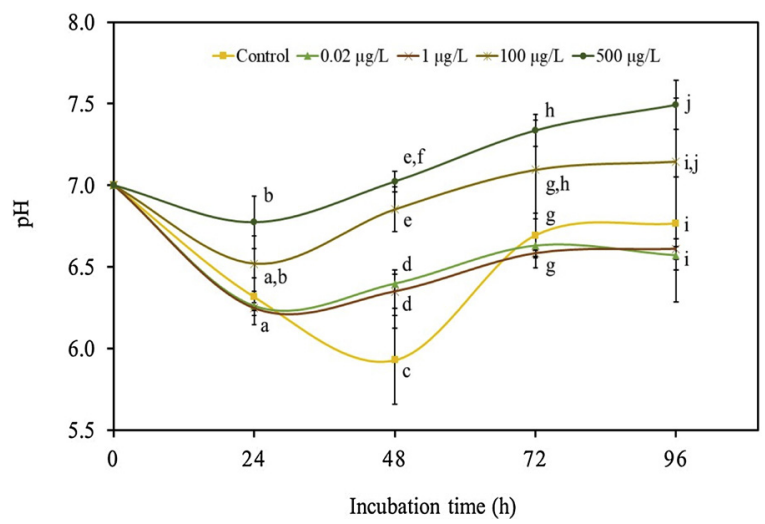

Fig. 3. $\mathrm{pH}$ variation during the $96 \mathrm{~h}$ experiment for the control and each of the DBP exposed conditions. Distinct letters represent means significantly different $(p<0.05)$. 


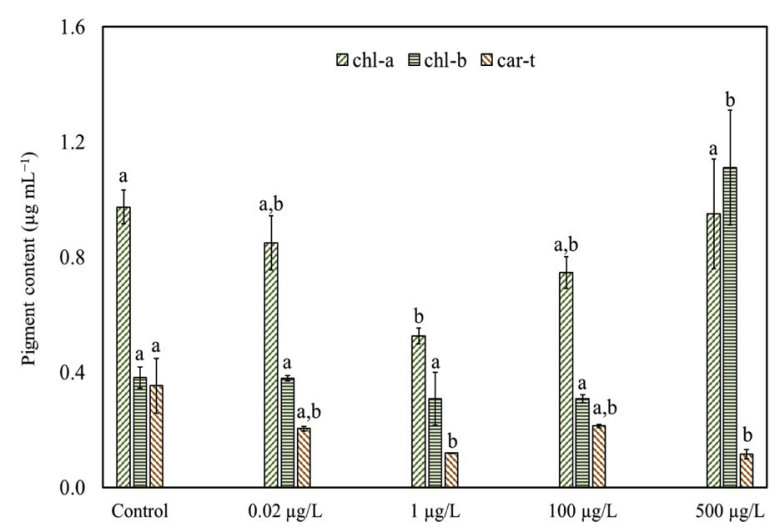

Fig. 4. Effect of DBP on the photosynthetic pigments: chlorophyll-a (chl-a), chlorophyll-b (chl-b) and total carotenoids (car-t), after $96 \mathrm{~h}$ of experimental exposition conditions. Distinct letters represent means significantly different of the same pigment between distinct conditions $(p<0.05)$.

condition displayed the steepest $\mathrm{pH}$ increase, with an increase of $0.5 \mathrm{pH}$ units.

\subsection{Photosynthetic pigment production}

The production of chlorophyll-a, chlorophyll-b and carotenoids were assessed with the results being shown in Fig. 4. After $96 \mathrm{~h}$, a consistent decrease was observed in all the photosynthetic pigments studied in the $0.02,1$ and $100 \mu \mathrm{g} \mathrm{L}^{-1}$ conditions. For the $500 \mu \mathrm{g} \mathrm{L}^{-1}$ concentration an inversion in this behaviour was observed, exhibiting an increase in the production of these pigments, except for the total carotenoids.

\subsection{Extracellular protein production}

The production of extracellular proteins in the DBP exposed conditions was determined after $96 \mathrm{~h}$ of being in the experimental exposure conditions. The results displayed in Fig. 5 show a slight, but not significant $(p<0.05)$ increase, between the $0.02,1$ and $100 \mu \mathrm{L} \mathrm{L}^{-1}$ conditions and the control. However, under the $500 \mu \mathrm{g} \mathrm{L}^{-1}$ DBP exposure, a significant $(p<0.05)$ increase in protein production was observed.

\subsection{Extracellular carbohydrates production}

The extracellular carbohydrates production was also evaluated at the end of the $96 \mathrm{~h}$ experiment. The results shown in Fig. 6 indicate a decreasing trend in the production of extracellular carbohydrates in the

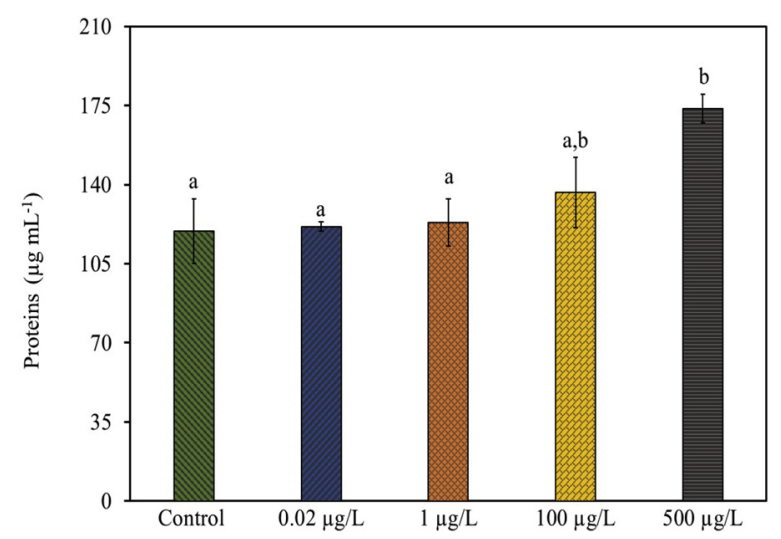

Fig. 5. Effect of DBP in the production of extracellular proteins, after $96 \mathrm{~h}$ of experimental exposition conditions. Distinct letters represent means significantly different $(p<0.05)$.

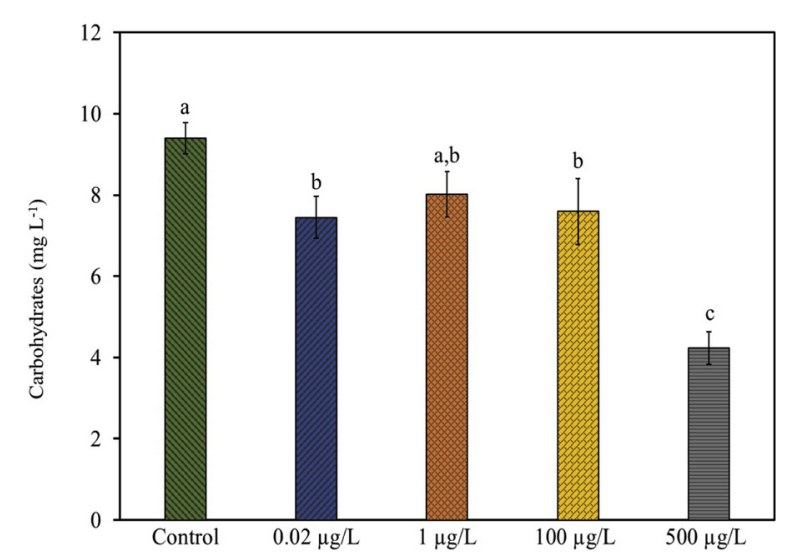

Fig. 6. Effect of DBP on the production of extracellular carbohydrates, after $96 \mathrm{~h}$ of experimental exposition conditions. Distinct letters represent means significantly different $(p<0.05)$.

presence of DBP, when compared to the control. The 0.02 and $100 \mu \mathrm{L} \mathrm{L}^{-1}$ conditions displayed a minor but significant $(p<0.05)$ decrease of extracellular carbohydrates production, when compared to the control condition but no significant differences were found between them. The $500 \mu \mathrm{g} \mathrm{L}^{-1}$ condition exhibited a sharper decrease $(p<$ 0.05 ) in relation to the control and also to the environmental concentrations $\left(0.02,1\right.$ and $\left.100 \mu \mathrm{g} \mathrm{L}^{-1}\right)$.

\section{Discussion}

This study aims to evaluate the interactions between phthalate esters, namely DBP, which are aquatic pollution components that are highly present in microplastics, and primary microorganism producers - microalgae - that constitute the base of the aquatic trophic system. Therefore, the growth and the biochemical parameters: $\mathrm{pH}$, photosynthetic pigments, proteins and carbohydrates production were studied in the freshwater microalga Scenedesmus sp., induced by the presence of DBP, in different environmental - 0.02, 1 and $100 \mu \mathrm{g} \mathrm{L}^{-1}$ - and laboratory - $500 \mu \mathrm{g} \mathrm{L} \mathrm{L}^{-1}$ - concentrations.

\subsection{DBP stability and effect on the microalga growth}

The DBP stability study made by UHPLC analysis showed that the DBP concentration only significantly varied during the first $48 \mathrm{~h}$ of the experiment. The ability of microalgae, including Scenedesmus species, to biodegrade phthalate esters, namely DBP among other phthalates, have been shown by Huang et al. (1999); Gao and Wen (2015b) and Zhang et al. (2016). Thus, since the stability was assessed in an algal-free culture medium, this fluctuation was likely due to the losses from the evaporation and sorption to the glass walls of the experimental system (Wezel et al., 2000).

The growth results (Fig. 12) of the control with and without methanol show that the presence of the organic solvent by itself did not affect the microalgal growth. Thus, the results regarding the growth when exposed to the different concentrations of DBP are only attributed to the presence of the pollutant.

The growth inhibition results show that, under our experimental conditions $\left(0.02,1,100\right.$ and $\left.500 \mu \mathrm{g} \mathrm{L}^{-1}\right)$, Scenedesmus sp. is susceptible to the effects of DBP in environmental concentrations, in a dose-dependent manner. Results shown by Kuang et al. (2003) display a cell density decrease from 26 to $51 \%$, in concentrations ranging from 10 to $60 \mathrm{mg} \mathrm{L}^{-1}$, in a dose-dependent manner. These results contradict the results shown by Wang et al. (2011), that found growth inhibition but no dose-response upon relatively low $\left(2-2000 \mu \mathrm{g} \mathrm{L}^{-1}\right)$ Scenedesmus obliquus DBP concentrations exposure. Still, higher concentrations (5-80 $\mathrm{mg} \mathrm{L}^{-1}$ ) of a similar phthalate (di-(2-ethylhexyl) phthalate) has 
been tested on Scenedesmus obliquus, and the same dose-dependent growth response found in our results has been established (Wang et al., 2010). Therefore, literature results on the dose-response establishment are somewhat contradictory, which may imply distinct defence mechanisms and miscellaneous biological responses at different concentration ranges. Wezel et al. (2000) reports NOEC (no observed effect concentration) and $\mathrm{L}(\mathrm{E}) \mathrm{C}_{50}$ (read $\mathrm{EC}_{50}$ ) values of 6.1 and $4.2 \mathrm{mg} \mathrm{L}^{-1}$ for DBP exposed Scenedesmus subspicatus. Other literature results show $96 \mathrm{~h}-$ $\mathrm{EC}_{50}$ values of $30.2 \mathrm{mg} \mathrm{L}^{-1}$ for Scenedesmus obliquus (Kuang et al., 2003; Wang et al., 2011), as well as $48 \mathrm{~h}-\mathrm{EC}_{50}$ and $72 \mathrm{~h}-\mathrm{EC}_{50}$ values of 9.0 and $2.0 \mathrm{mg} \mathrm{L}^{-1}$, respectively, for Scenedesmus subspicatus upon DBP exposure (Wezel et al., 1999). The results of this study: a $48 \mathrm{~h}-\mathrm{EC}_{50}$ of $41.88 \mu \mathrm{g} \mathrm{L}^{-1}$ and a LOEC of $1 \mu \mathrm{g} \mathrm{L}^{-1}$ show that these values are lower than those found in the literature, highlighting the hazardous nature of the DBP exposure to microalgae, specifically Scenedesmus sp., in environmental concentrations.

The exhibited toxic effects are not exclusive to microalgae, as corroborated from the observations made by Ohtani et al. (2000) that DBP behaves as an endocrine disruptor in other species such as the frog Rana rugosa. The decrease in the growth in the first $24 \mathrm{~h}$ is likely due to the adaptation and higher surface accumulation of DBP by the microalga with no major biomass development (Chi et al., 2006). This effect is enhanced at higher concentrations $\left(500 \mu \mathrm{g} \mathrm{L}^{-1}\right)$, causing a greater growth inhibition in the first $48 \mathrm{~h}$. After this period the microalga seems to adapt gradually to the presence of DBP, consequently entering an exponential growth phase. The $\mathrm{pH}$ measurements corroborate the observations made in the growth curves, decreasing in the first $24 \mathrm{~h}$ (in the $0.02,1$ and $100 \mu \mathrm{g} \mathrm{L}^{-1}$ conditions) and until $48 \mathrm{~h}\left(500 \mu \mathrm{g} \mathrm{L}^{-1}\right)$ and then gradually increasing. This behaviour may be attributed to the assimilation of carbon and nitrogen sources in the medium (Zhang et al., 2016), during cell growth. Also, the $\mathrm{pH}$ increase is directly related to the $\mathrm{CO}_{2}$ decrease (Bhattacharya et al., 2010), consequence of higher photosynthetic rates.

\subsection{DBP influence on photosynthetic pigment production}

The results observed in the photosynthetic pigment content assay showed that the environmental concentrations $\left(0.02,1\right.$ and $\left.100 \mu \mathrm{g} \mathrm{L}^{-1}\right)$ of DBP might have a more negative influence on the pigment content than higher $\left(500 \mu \mathrm{g} \mathrm{L}^{-1}\right)$ laboratory concentrations. Kuang et al. (2003) reported a chlorophyll-a (chl-a) decrease from 24.4 to $60.7 \%$ in the presence of high (10-60 $\mathrm{mg} \mathrm{L}^{-1}$ ) concentrations of DBP, corroborating the observations made here. Therefore, the effects of DBP on the production of chl-a are presumed to occur both in environmental relevant (especially in the $1 \mu \mathrm{g} \mathrm{L}^{-1}$ concentration) and higher laboratory concentrations. Also, Wang et al. (2010) reported for Scenedesmus obliquus, that in the presence of high di-(2-ethylhexyl) phthalate concentrations the cell growth did not correlate with chlorophyll and carotenoids biosynthesis, although in unrealistic environmental concentrations (5-80 $\mathrm{mg} \mathrm{L}^{-1}$ ). As discussed in 4.1., it is expected that a $\mathrm{pH}$ increase is observed when the photosynthetic rates go up. The fact that our results show increasing $\mathrm{pH}$ values while the photosynthetic pigment production decreased, makes it uncertain to guarantee the occurrence of oxidative stress. The $\mathrm{pH}$ increased until the end of the experiment, with the growth and inhibition likely taking place due to DBP cell-surface accumulation.

Although the production of chl-b (chlorophyll $b$ ) only suffered significant changes $(p<0.05)$ in the $500 \mu \mathrm{g} \mathrm{L}^{-1}$ DBP exposure, the production of chl-a (chlorophyll $a$ ) and car-t (total carotenoids) exhibited significant changes $(p<0.05)$ amongst conditions. It is common that microalgae produce reactive oxygen species (ROS) derived from oxidative stress. This damages the chloroplasts which negatively affects the growth and photosynthetic production (Wang et al., 2010) and consequently decrease the pH. Reports from Bhattacharya et al. (2010) show that the production of ROS increases with exposure time, with the microalgae displaying distinct response stages depending on the exposure period to microplastics that might contain phthalates that are likely slowly released into the medium. Other literature results regarding the DBP exposure in distinct microalgae are inconsistent. It has been shown that DBP stimulates the activity of antioxidant enzyme systems of the dinoflagellate Karenia brevis : superoxide dismutase (SOD) and catalase (CAT) (Liu et al., 2016; Li et al., 2015). Also, Chunxiao et al. (2015) report, for Microcystis aeruginosa, an increase in SOD and CAT activity in the $1-4 \mathrm{mg} \mathrm{L}^{-1}$ DBP concentration range, but inhibition takes place for $8 \mathrm{mg} \mathrm{L}^{-1}$. Further research correlating the production of ROS, the activity of SOD and CAT, as well as the $\mathrm{pH}$ variation and chlorophyll production would be required to further understand the mechanisms behind phthalates action on microalgae.

\subsection{DBP influence on extracellular protein production}

Regarding the extracellular protein production, it was shown that it might be upregulated by the presence of the phthalate. To the best of our knowledge, this is the first study exploring the effects of DBP and any type of phthalate on the extracellular protein production of microalgae. DBP can act as a xenoestrogen, that can potentially bind to oestrogen receptor sites (Müller et al., 2000). It is hypothesized that DBP is able to bind to the estradiol receptors. This could trigger the binding of a ligand-receptor complex to the DNA, and consequently induce transcription and protein production (Wezel et al., 2000). Despite a DBP dose-correlated protein production increase, only the $500 \mu \mathrm{g} \mathrm{L}^{-1}$ condition observed a significant increase, when comparing with the control and the environmental concentrations $(0.02,1$ and $100 \mu \mathrm{g} \mathrm{L}^{-1}$ ). This indicates that higher DBP concentrations stimulate protein production. Some authors found similar effects on different and more complex aquatic organisms, with Zhou et al. (2015) showing similar effects on the general upregulation in the extracellular protein production in the presence of factual DBP concentrations $\left(2-50 \mu \mathrm{L} \mathrm{L}^{-1}\right)$ on abalone (Haliotis diversicolor supertexta). Also, a study on duckweeds Spirodela polyrhiza and Lemna minor biochemical response to DBP shows a decrease in the extracellular protein in the $0-500 \mu \mathrm{g} \mathrm{L}^{-1}$ range, with a major decline in higher concentrations (1-7.5 $\mathrm{mg} \mathrm{L}^{-1}$ ) (Huang et al., 2006). Therefore, with the current available data, it is possible to assume that the DBP influence on extracellular protein production is organism- and dose-dependent, with environmental concentrations acting as an up-regulator in the protein production for Scenedesmus sp..

\subsection{DBP influence on extracellular carbohydrates production}

Similarly, to the extracellular protein production evaluation, this is also, to the best of our knowledge, the first study assessing the effects of DBP and any type of phthalate on the production of extracellular carbohydrates by microalgae. The results regarding the extracellular carbohydrates production exhibit a dose-dependent correlation for its downregulation. Scenedesmus sp. displayed a high sensibility in the presence of DBP regarding the extracellular carbohydrates production, even at the lowest concentration $\left(0.02 \mu \mathrm{L} \mathrm{L}^{-1}\right)$. Zhou et al. (2015) showed that this effect is not exclusive to microalgae but also more complex aquatic organisms, with a decrease of glucose in the abalone Haliotis diversicolor supertexta, in the presence of factual DBP concentrations $\left(2-50 \mu \mathrm{g} \mathrm{L}^{-1}\right)$. Lee (2000) showed that DBP acts as a slowbinding, non-competitive but reversible inhibitor of the bacterial Streptomyces melanosporofaciens $\alpha$-glucosidases, also inhibiting $\beta$-glucosidases, as well as $\alpha$ - and $\beta$-mannosidases. Therefore, DBP has the potential to interfere with the overall balance of carbohydrates production, affecting the processing of glycoproteins, glycolipids and the digestion of carbohydrates. This could consequently disturb the glucose expression and its related transcriptional elements and transporters (Kawamoto et al., 2005). 


\subsection{Call for research}

Regarding the exponential aquatic plastic pollution and the increasing global concern, it is expected that the levels of plastic-bound pollutants released into the environment increase. Aside from being global players in oxygen production, microalgae also constitute the base of the aquatic food chain. However, these unicellular photosynthetic organisms are sensitive to environmental risks. These microorganisms produce biovaluable molecules such as pigments, proteins and carbohydrates, among others, that are essential in the equilibrium of its ecosystems. Our study shows that the production of these molecules is unregulated by the presence of phthalates, namely DBP. Therefore, the aquatic ecosystem equilibrium is put at risk when the natural balance is disrupted.

Still, the data regarding the risk assessment of phthalates to microalgae is very scarce, and the end points not wide and complex enough to better understand the real consequences of the exponentially increasing phthalates exposure derived from plastic pollution. Thus, the authors call for more in-depth research on the susceptibility and the inhibitory mechanisms of microalgae when exposed to environmentally occurring concentrations of toxic plastic-bonded pollutants, primarily phthalates.

\section{Conclusions}

The aim of this study was to evaluate the effects of natural environmentally occurring $\left(0.02,1\right.$ and $\left.100 \mu \mathrm{L} \mathrm{L}^{-1}\right)$ and higher laboratory $\left(500 \mu \mathrm{g} \mathrm{L}^{-1}\right)$ concentrations of DBP on the biochemical behaviour of Scenedesmus sp. This would include its growth, $\mathrm{pH}$ variation, photosynthetic pigments, extracellular proteins and carbohydrates production. The obtained results showed that DBP exposure had a steeper effect on the microalgal growth in the first $48 \mathrm{~h}$. By gathering the data from the $\mathrm{pH}$ variation and photosynthetic pigments production, it was not possible to assure the occurrence of oxidative stress. The only increase in the photosynthetic pigments production, namely chlorophylla and chlorophyll-b, was recorded in the $500 \mu \mathrm{L}^{-1}$ condition. Therefore, the environmental concentrations of phthalates might have a higher negative influence on the pigment content than the higher DBP concentrations. For the lower concentrations tested, the extracellular protein production observed a consistent increase. Furthermore, a significant increase in the extracellular protein production was observed in the $500 \mu \mathrm{g} \mathrm{L}^{-1}$ DBP exposure condition. In the concentrations tested, particularly in the higher concentration, the extracellular carbohydrates production was significantly downregulated in the presence of DBP. This suggests that when DBP acts as an inhibitor of glycosidases, it negatively influences the production of extracellular carbohydrates.

The results of this work call for more in-depth research on the concentration-dependent susceptibility and mechanisms of microalgae when exposed to environmentally occurring concentrations of toxic plastic-bonded pollutants.

\section{Acknowledgements}

This work was partially supported by the project REBECA (MAC/ 1.1a/060) European Territorial Cooperation Programme PCT-MAC 2014-2020 through project REBECA (MAC/1.1a/060) and the Oceanic Observatory of Madeira Project (M1420-01-0145-FEDER-000001). The authors acknowledge the Spanish Bank of Algae (BEA) for making the microalga available.

\section{References}

Bakir, A., Rowland, S., Thompson, R., 2014. Transport of persistent organic pollutants by microplastics in estuarine conditions. Estuar. Coast. Shelf Sci. 140, 14-21. https:// doi.org/10.1016/j.ecss.2014.01.004.

Babu, B., Wu, J.T., 2010. Production of phthalate esters by nuisance freshwater algae and cyanobacteria. Sci. Total Environ. 408, 4969-4975. https://doi.org/10.1016/j. scitotenv. 2010.07.032.

Besseling, E., Wegner, A., Foekema, E., Heuvel-Greve, M., Koelmans, A., 2013. Effects of Microplastics on Fitness and PCB Bioaccumulation by the LugwormArenicola marina (L.). American Chemical Society 47 (1), 593-600. https://doi.org/10.1021/ es302763x.

Bhattacharya, P., Lin, S., Turner, J., Ke, P., 2010. Physical adsorption of charged plastic nanoparticles affects algal photosynthesis. J. Phys. Chem. C 633 (15), 500-507. https://doi.org/10.1021/jp1054759.

Cambiaire, J., Otis, C., Lemieux, C., Turmel, M., 2006. The complete chloroplast genome sequence of the chlorophycean green alga Scenedesmus obliquus reveals a compact gene organization and a biased distribution of genes on the two DNA strands. BMC Evol. Biol. 6 (1), 1-15. https://doi.org/10.1186/1471-2148-6-37.

Chi, J., Liu, H., Li, B., Huang, G., 2006. Accumulation and Biodegradation of Dibutyl Phthalate in Chlorella vulgaris. Bull. Environ. Contam. Toxicol. 77 (1), 21-29. https://doi.org/10.1007/s00128-006-1027-6.

Chunxiao, L., Ping, W., Haiyan, L., Xinchun, W., Weiliang, Y., 2015. Effects of Dibutyl Phthalate on Growth and Enzymatic Antioxidants of Microcystis aeruginosa. Environ. Sci. Technol. 38, 7-12.

Cunha, C., Faria, M., Nogueira, N., Ferreira, A., Cordeiro, N., 2019. Marine vs freshwater microalgae exopolymers as biosolutions to microplastics pollution. Environ. Pollut. 249 (0), 372-380. https://doi.org/10.1016/j.envpol.2019.03.046.

Duan, K., Cui, M., Wu, Y., Huang, X., Xue, A., Deng, X., Luo, L., 2018. Effect of Dibutyl Phthalate on the Tolerance and Lipid Accumulation in the Green Microalgae Chlorella vulgaris. Bull. Environ. Contam. Toxicol. 101 (3), 338-343. https://doi. org/10.1007/s00128-018-2385-6.

Desforges, J., Galbraith, M., Dangerfield, N., Ross, P., 2014. Widespread distribution of microplastics in subsurface seawater in the NE Pacific Ocean. Mar. Pollut. Bull. 79 (1), 94-99. https://doi.org/10.1016/j.marpolbul.2013.12.035.

Endo, S., Takizawa, R., Okuda, K., Takada, H., Chiba, K., Kanehiro, H., Ogi, H., Yamashita, R., Date, T., 2015. Concentration of polychlorinated biphenyls (PCBs) in beached resin pellets: variability among individual particles and regional differences. Marina Pollution Bulletin. 50 (10), 1103-1114. https://doi.org/10.1016/j. marpolbul.2005.04.030.

Fatoki, O., Bomman, M., Ravandhalala, L., Chimuka, L., Genthe, B., Adeniyi, A., 2010. Phthalate ester plasticizers in freshwater systems of Venda, South Africa and potential health effects. Water Sa 36 (1), 117-126. https://doi.org/10.4314/wsa.v36i1. 50916.

Frias, P., Sobral, P., Ferreira, M., 2010. Organic pollutants in microplastics from two beaches of the Portuguese coast. Mar. Pollut. Bull. 60 (11), 1988-1992. https://doi. org /10.1016/j.marpolbul.2010.07.030.

Fries, E., Dekiff, J., Willmeyer, J., Nuelle, M., Ebert, M., Remy, D., 2013. Identification of polymer types and additives in marine microplastic particles using pyrolysis-GC/MS and scanning electron microscopy. Environ. Sci. Process. Impacts 15 (10), 1946-1956. https://doi.org/10.1039/c3em00214d.

Gao, D., Wen, Z., 2015a. Phthalate esters in the environment: a critical review of their occurrence, biodegradation, and removal during wastewater treatment processes. Sci. Total Environ. 541, 986-1001. https://doi.org/10.1016/j.scitotenv.2015.09.148.

Gao, D., Wen, Z., 2015b. Biodegradation of phthalate acid esters by different marine microalgal species. Mar. Pollut. Bull. 99 (1-2), 70-75. https://doi.org/10.1016/j. marpolbul.2015.07.061.

GESAMP, 2015. Source, Fate and Effects of Microplastics in the Marine Environment: A Global Assessment. International Maritime Organization.

Gu, S., Zheng, H., Xu, Q., Sun, C., Shi, M., Wang, Z., Li, F., 2017. Comparative Toxicity of the Plasticizer Dibutyl Phthalate to Two Freshwater Algae. Aquat. Toxicol. 191, 122-130. https://doi.org/10.1016/j.aquatox.2017.08.007.

Hirai, H., Takada, H., Ogata, Y., Yamashita, R., Mizukawa, K., Saha, M., Kwan, C., Moore, C., Gray, H., Laursen, D., Zettler, R., Farrington, W., Reddy, M., Peacock, E., Ward, W., 2011. Organic micropollutants in marine plastics debris from the open ocean and remote and urban beaches. Mar. Pollut. Bull. 62 (8), 1683-1692. https://doi.org/10. 1016/j.marpolbul.2011.06.004.

Huang, G., Sun, H., Song, Z., 1999. Interactions between dibutyl phthalate and aquatic organisms. Bull. Environ. Contam. Toxicol. 63 (6), 759-765. https://doi.org/10. 1007/s001289901044.

Huang, Q., Wang, Q., Tan, W., Song, G., Lu, G., Li, F., 2006. Biochemical Responses of Two Typical Duckweeds Exposed to Dibutyl Phthalate. J. Environ. Sci. Health A. Tox. Subst. Environ. Eng. 41 (8), 1615-1626. https://doi.org/10.1080/ 10934520600754185.

Hurley, R., Wooward, J., Rothwell, J., 2018. Microplastic contamination of river beds significantly reduced by catchment-wide flooding. Nat. Geosci. 11, 251-257. https:// doi.org/10.1038/s41561-018-0080-1.

Kawamoto, H., Morita, T., Shimizu, A., Inada, T., Aiba, H., 2005. Implication of membrane localization of target mRNA in the action of a small RNA: mechanism of posttranscriptional regulation of glucose transporter in Escherichia coli. Genes Dev. 19 (3), 328-338. https://doi.org/10.1101/gad.1270605.

Kuang, Q., Zhao, W., Cheng, S., 2003. Toxicity of Dibutyl Phthalate to Algae. Bull. Environ. Contam. Toxicol. 71 (3), 602-608. https://doi.org/10.1007/s00128-0038559-9.

Jonsson, S., Baun, A., 2003. Toxicity of mono- and diesters of o-phthalic esters to a crustacean, a green alga, and a bacterium. Environ. Toxicol. Chem. 22 (12), 3037-3043. https://doi.org/10.1897/02-548.

Li, F.M., Wu, M., Yao, Y., Zheng, X., Zhao, J., Wang, Z.Y., Xing, B.S., 2015. Inhibitory effects and oxidative target site of dibutyl phthalate on Karenia brevis. Chemosphere. 132, 32-39. https://doi.org/10.1016/j.chemosphere.2015.01.051.

Liu, N., Wen, F., Li, F., Zheng, X., Liang, Z., Zheng, H., 2016. Inhibitory mechanism of phthalate esters on Karenia brevis. Chemosphere. 155, 498-508. https://doi.org/10. 
1016/j.chemosphere.2016.04.082.

Lee, D., 2000. Dibutyl phthalate, an $\alpha$-glucosidase inhibitor from Streptomyces melanosporofaciens. J. Biosci. Bioeng. 89 (3), 271-273. https://doi.org/10.1016/S13891723(00)88832-5.

Lichtenthaler, H., 1987. Chlorophylls and carotenoids: Pigments of photosynthetic biomembranes. Meth. Enzymol. 148, 350-382. https://doi.org/10.1016/0076-6879(87) 48036-1.

Lowry, O., Rosebrough, N., Farr, A., Randall, R., 1951. Protein Measurement with the Folin Phenol Reagent. J. Biol. Chem. 193 (1), 265-275.

Mandal, S., Mallick, N., 2009. Microalga Scenedesmus obliquus as a potential source for biodiesel production. Appl. Microbiol. Biotechnol. 84 (2), 281-291. https://doi.org/ 10.1007/s00253-009-1935-6.

Mason, S., Welch, V., Neratko, J., 2018. Synthetic Polymer Contamination in Bottled Water. 407 (6), 1-17. https://doi.org/10.3389/fchem.2018.00407.

Mato, Y., Isobe, T., Takada, H., Kanehiro, H., Ohtake, C., Kaminuma, T., 2001. Plastic resin pellets as a transport medium for toxic chemicals in the marine environment. Environ. Sci. Technol. 35 (2), 318-324. https://doi.org/10.1021/es0010498.

Müller, W., Koziol, C., Wiens, M., Schröder, H., 2000. Stress response in marine sponges: genes and molecules involved and their use as biomarkers. Chapter 14. Cell and Molecular Response to Stress. 1, 193-208. https://doi.org/10.1016/S1568-1254(00) 80016-9.

Nerland, I., Halsband, C., Allan, I., Thomas, K., 2014. Microplastics in Marine Environments: Occurrence, Distribution and Effects. Norsk institutt for vannforskning, pp. 6-71.

OECD/OCDE, 2011. OECD Guidelines for the Testing of Chemicals: Freshwater Alga and Cyanobacteria. Growth Inhibition Test.

Ohtani, H., Miura, I., Ichikawa, Y., 2000. Effects of Dibutyl Phthalate as an Environmental Endocrine Disruptor on Gonadal Sex Differentiation of Genetic Males of the Frog Rana rugosa. Environ. Health Perspect. 108 (12), 1189-1193. https://doi.org/10. 1289/ehp.001081189.

Peeken, I., Primpke, S., Beyer, B., Gütermann, J., Katlein, C., Krumpen, T., Bergmann, M., Hehemann, L., Gerdts, G., 2018. Arctic sea ice is an important temporal sink and means of transport for microplastic. Nat. Commun. 9 (1), 1-12. https://doi.org/10. 1038/s41467-018-03825-5.

Ryan, P.G., 2015. A brief history of marine litter research. Marine Anthropogenic Litter. 1-25. https://doi.org/10.1007/978-3-319-16510-3_1.

Teuten, E., Rowland, S., Galloway, T., Thompson, R., 2007. Potential for plastics to transport hydrophobic contaminants. Environ. Sci. Technol. 41 (22), 7759-7764. https://doi.org/10.1021/es071737s.

UN environment, 2018. World environment day 2018: overview. Sci. Total Environ. 1-4.

Waller, C., Griffiths, H., Waluda, C., Thorpe, S., Loaiza, I., Moreno, B., Pacherres, C., Hughes, K., 2017. Microplastics in the Antarctic marine system: An emerging area of research. Sci. Total Environ. 598, 220-227. https://doi.org/10.1016/j.scitotenv. 2017.03.283.

Wang, L., Wei, C., Yang, X., Tang, L., 2010. Di-(2-ethylhexyl) phthalate toxic effect on scenedesmus obliquus evaluated by the biomarkers of inhibition rate and pigment content. $20104^{\text {th }}$ International Conference on Bioinformatics and Biomedical Engineering. https://doi.org/10.1109/ICBBE.2010.5515282.

Wang, Z., Hu, F., Song, W., Guo, J., He, W., 2011. Chronic toxic effect of Three estrogens to algae (Scenedesmus obliquus). 2011 International Conference on Human Health and Biomedical Engineering. https://doi.org/10.1109/HHBE.2011.6028962.

Wezel, A., Posthumus, R., Vlaardingen, P., Crommentujin, G., Plassche, E., 1999. Maximum Permissible Concentrations and Negligible Concentrations for Phthalates (dibutylphthalate and Di(2-ethyl-hexyl) Phthalate), With Special Emphasis on Endocrine Disruptive Properties. Research for Man and Environment.

Wezel, A., Vlaardingen, P., Posthumus, R., Crommentujin, G., Sjim, D., 2000. Environmental risk limits for two phthalates, with special emphasis on endocrine disruptive properties. Ecotoxicol. Environ. Saf. 46 (3), 305-321. https://doi.org/10. 1006/eesa.2000.1930.

Zhang, X., Liu, L., Zhang, S., Pan, Y., Li, J., Pan, H., Xu, S., Luo, F., 2016. Biodegradation of dimethyl phthalate by freshwater unicellular Cyanobacteria. Biomed Res. Int. 1-8. https://doi.org/10.1155/2016/5178697.

Zhou, J., Chen, B., Cai, Z., 2015. Metabolomics-based approach for assessing the toxicity mechanisms of dibutyl phthalate to abalone (Haliotis diversicolor supertexta). Environ. Sci. Pollut. Res. - Int. 22 (7), 5092-5099. https://doi.org/10.1007/s11356-0143859-7. 